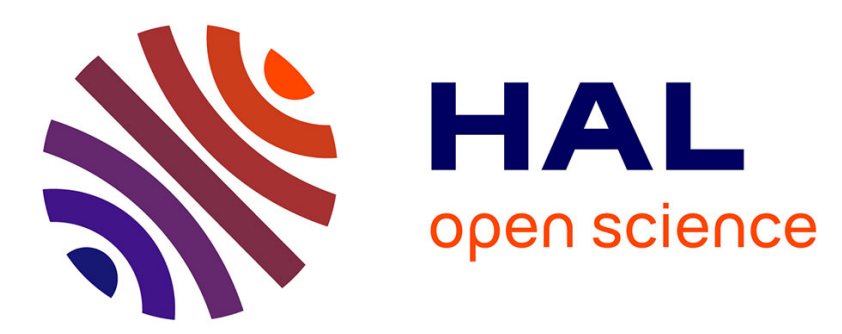

\title{
Developing a Highly Active Catalytic System Based on Cobalt Nanoparticles for Terminal and Internal Alkene Hydrosilylation
}

\author{
Martin Jakoobi, Vincent Dardun, Laurent Veyre, Valérie Meille, Clément \\ Camp, Chloé Thieuleux
}

\section{To cite this version:}

Martin Jakoobi, Vincent Dardun, Laurent Veyre, Valérie Meille, Clément Camp, et al.. Developing a Highly Active Catalytic System Based on Cobalt Nanoparticles for Terminal and Internal Alkene Hydrosilylation. Journal of Organic Chemistry, 2020, 85 (18), pp.11732-11740. 10.1021/acs.joc.0c01439 . hal-02998618

\section{HAL Id: hal-02998618 \\ https://hal.science/hal-02998618}

Submitted on 10 Nov 2020

HAL is a multi-disciplinary open access archive for the deposit and dissemination of scientific research documents, whether they are published or not. The documents may come from teaching and research institutions in France or abroad, or from public or private research centers.
L'archive ouverte pluridisciplinaire HAL, est destinée au dépôt et à la diffusion de documents scientifiques de niveau recherche, publiés ou non, émanant des établissements d'enseignement et de recherche français ou étrangers, des laboratoires publics ou privés. 


\title{
Developing a Highly Active Catalytic System Based on Cobalt Nanopar- ticles for Terminal and Internal Alkene Hydrosilylation
}

\author{
Martin Jakoobi, ${ }^{\dagger}$ Vincent Dardun, ${ }^{\dagger}$ Laurent Veyre ${ }^{\dagger}$ Valérie Meille, ${ }^{\S}{ }^{\ddagger}$ Clément Camp ${ }^{\dagger}$ and Chloé Thieu- \\ leux $*, \dagger$
}

'Université de Lyon, Institut de Chimie de Lyon, Laboratory of Chemistry, Catalysis, Polymers and Processes, C2P2 UMR 5265 CNRS-UCB Lyon 1-CPE Lyon, 43 Bd du 11 Novembre 1918, F-69616 Villeurbanne, France

${ }^{\S}$ Université de Lyon, Institut de Chimie de Lyon, Laboratoire de Génie des Procédés Catalytiques, UMR 5285 CNRS-UCB

Lyon 1-CPE Lyon, CPE Lyon, 43 Bd du 11 Novembre 1918, F-69616 Villeurbanne, France

KEYWORDS. Colloidal catalyst, cobalt nanoparticles, alkene hydrosilylation, tertiary silanes, tandem catalysis.

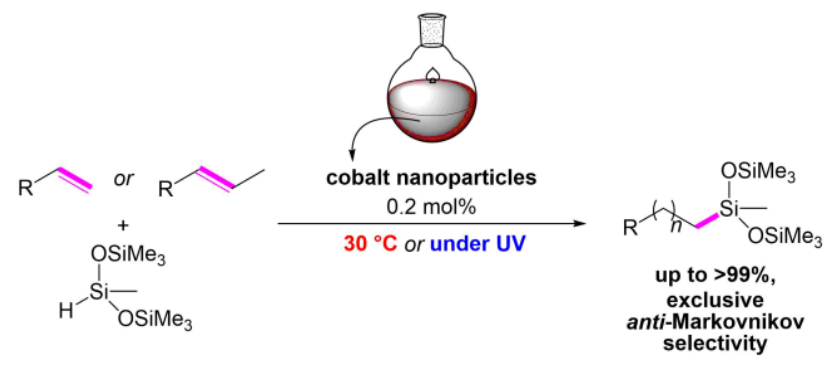

\begin{abstract}
This work describes the development of easy to prepare cobalt nanoparticles (NPs) in solution as promising alternative catalysts for alkene hydrosilylation with the industrially relevant tertiary silane $\mathrm{MD}^{\mathrm{H}} \mathrm{M}(1,1,1,3,5,5,5$-heptamethyltrisiloxane). The Co NPs demonstrated high activity when used at $30{ }^{\circ} \mathrm{C}$ for $3.5-7 \mathrm{~h}$ in toluene, with catalyst loadings $0.05-0.2 \mathrm{~mol} \%$, without additives. Under these mild conditions, a set of terminal alkenes were found to react with $\mathrm{MD}^{\mathrm{H}} \mathrm{M}$, yielding exclusively the antiMarkovnikov product in up to $99 \%$ yields. Additionally, we demonstrated the possibility of using UV irradiation to further activate these cobalt NPs in order to enhance their catalytic performances, but also to promote tandem isomerization-hydrosilylation reactions using internal alkenes, among them unsaturated fatty ester (methyl oleate), to produce linear products in up to quantitative yields.
\end{abstract}

\section{Introduction}

Alkene hydrosilylation is considered as a key reaction for the preparation of silicones and functional silanes. ${ }^{1}$ Currently, unsustainable platinum based complexes are still preferred in the industry and although ppm levels of catalyst are used, the difficulty to remove Pt from the reaction products leads to extra costs. For example, in the last year, the price of Pt ounce has varied over $20 \%$, which should furthermore incentivize the development of alternatives to precious metal based catalysts in the long run. ${ }^{2}$ One current major trend in this field is to replace platinum with non-noble metal species. Pioneering reports in 1950s and 1960s described the use of Fe, Co and $\mathrm{Ni}$ complexes as alternatives to Pt. However, they were found either poorly selective with highly varying product yields in alkene hydrosilylation, accompanied by various side-reactions, or their use was limited to the catalytic alkene hydrosilylation with highly activated silanes. ${ }^{3,4}$ A major step forward was made by Chirik and co-workers in 2004 with the development of an iron-based complex bearing a pyridinediimine (PDI) ligand. ${ }^{5}$ This seminal work demonstrated that the use of a noninnocent PDI ligand led to a selective anti-Markovnikov type alkene hydrosilylation catalyst. Further advances by the same group allowed to broaden the silane scope to less active ter- tiary hydrosilanes and hydrosiloxanes with high product yields and selectivities. ${ }^{6-9}$ Additionally, very recently, other basemetal complexes containing pincer-type ligands such as amido(bisoxazoline), ${ }^{10}$ various pyridine-based ligands, ${ }^{11-13} \mathrm{~N}$ heterocyclic carbene ${ }^{14}$ and isocyanides ${ }^{15,16}$ were reported and shown to provide high catalytic activities in dehydrogenative silylation, Markovnikov and/or anti-Markovnikov hydrosilylation of alkenes. ${ }^{3,4,17}$ While very effective in catalysis, most of these complexes require the design and use of sophisticated ligands and additionally such complexes are highly sensitive to moisture or require the use of strong reductants or additives for catalyst activation.

An important alternative to homogeneous non-precious metal catalysts in alkene hydrosilylation is to develop analogous heterogeneous systems, which in the recent years has gained momentum. Current examples of heterogeneous non-precious metal catalysts capable of alkene hydrosilylation have been prepared as supported catalysts, ${ }^{18-20}$ by incorporating metals into metal organic frameworks ${ }^{21}$ or layers ${ }^{22}$ and as dispersed nanoparticles (NPs) onto supports ${ }^{19}$. While the latter examples boast at times with large alkene scopes, they are currently limited by the choice of the silane counterpart, which, in most cases, involves the use of activated silanes $\left(\mathrm{PhSiH}_{3}\right.$ and 
$\mathrm{Ph}_{2} \mathrm{SiH}_{2}$ ) that are not relevant for industrial applications. To bridge the gap between homogeneous and heterogeneous catalysis, non-supported metal NPs (i.e. suspended NPs in solution) have also recently been investigated. In this context, we demonstrated that Pt NPs exhibit the same catalytic performances (rate, TON) and selectivity as molecular Pt complexes (Karstedt complex for instance). ${ }^{23}$ These results strongly suggest that molecular complexes can be rapidly transformed into Pt NPs during the course of the reaction and that hydrosilylation of alkenes can be catalyzed by metallic surfaces. Along the same line, for base metals, only two literature precedents could be found. Obora et al. described the development of nanosized $\mathrm{Fe}_{2} \mathrm{O}_{3}$ NPs in solution as nanocatalysts for the hydrosilylation of activated silanes ${ }^{24}$ while $\mathrm{Hu}$ et al. depicted that a $\mathrm{Ni}$ alkoxide pre-catalyst, $\mathrm{Ni}(\mathrm{OtBu})_{2} \cdot \mathrm{xKCl}$, was rapidly transformed into Ni NPs during the hydrosilylation reaction and these NPs could be the catalyst for the hydrosilylation of non-activated silanes. ${ }^{25}$ We therefore decided to explore the possibility to develop structurally simple Co nanoparticles as alternatives to the reported catalytic systems.

\section{Results and Discussion}

In search for a more easily prepared transition metal catalyst for alkene hydrosilylation reactions, we developed here a protocol to synthesize well-defined cobalt nanoparticles in solution. The synthetic procedure to yield these NPs is simple and quite different from those classically used in the literature which require the use of surfactants (amines, ${ }^{26,27}$ carboxylic $\operatorname{acids}^{27,28}$ ), stabilizing agents (polymer, ${ }^{29,30}$ phosphine, ${ }^{31}$ olefin $^{32}$ etc.) and/or high temperature boiling solvents (dichlorobenzene, ${ }^{26}$ diphenyl ether ${ }^{33}$ ). In this study, the protocol used to synthesize the Co NPs is straightforward and is based on previous procedures developed in our group to generate other metal NPs. ${ }^{20,34}$ The resulting cobalt NPs catalysts (namely Co1 to Co-4) were prepared from commercially available $\mathrm{Co}_{2}(\mathrm{CO})_{8}$ in toluene in the presence of $n$-octylsilane (7.5 mol\% compared to Co-atom) as stabilizer under 4 bars of $\mathrm{H}_{2}$ at different temperatures from $140{ }^{\circ} \mathrm{C}$ (for $\mathrm{Co}-1$ ) to $60^{\circ} \mathrm{C}$ (for Co-4) (Fig. 1a).

The obtained Co-NPs were first characterized by scanning transmission electron microscopy (STEM-HAADF) and the corresponding results are presented in Table 1 and Figure $1 \mathrm{~b}$ for Co-4. These NPs are very small in size (ca. 1.6-2.1 nm) and their average size seems to be independent from the temperature $\left(60-140{ }^{\circ} \mathrm{C}\right)$ used for the NPs preparation (Table 1 and Fig. S1-S4). Additionally, UV-vis spectra were measured for all Co-NPs and for the starting material, $\mathrm{Co}_{2}(\mathrm{CO})_{8}$. According to Fig. 1c, the absorption band belonging to $\mathrm{Co}_{2}(\mathrm{CO})_{8}$ at $352 \mathrm{~nm}$ has disappeared for all Co-NPs systems, in agreement with the consumption of the starting material.
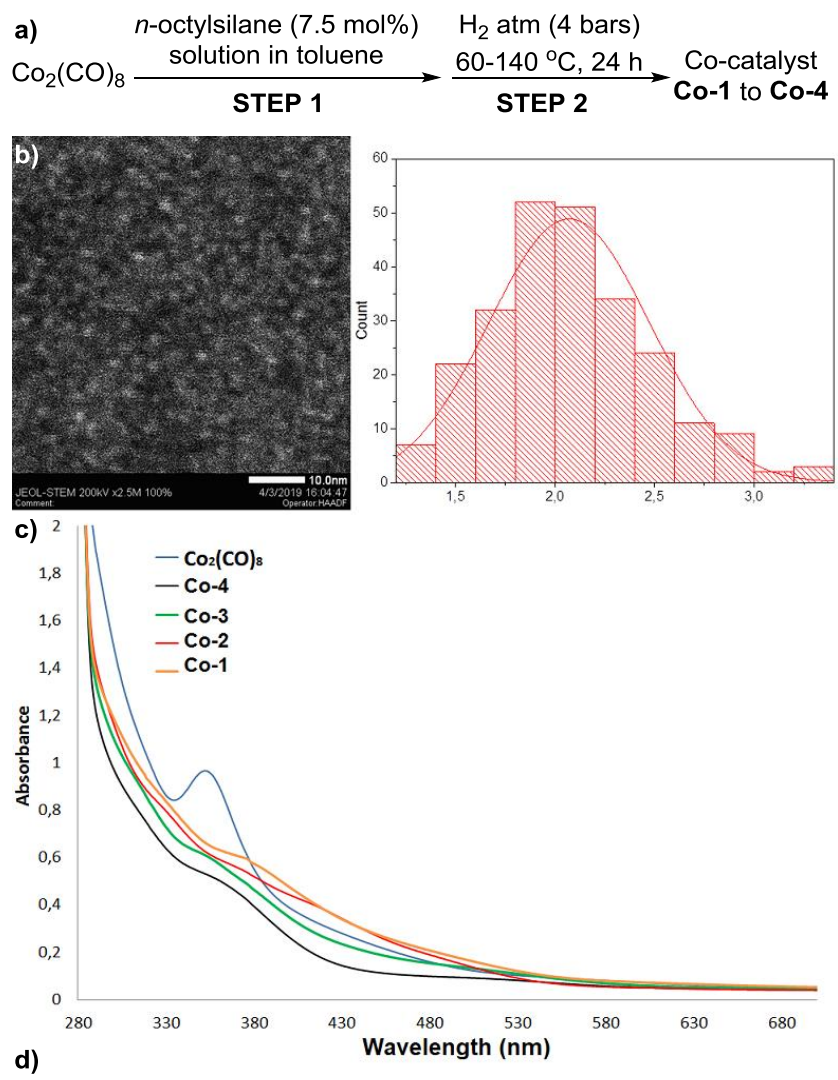

d)

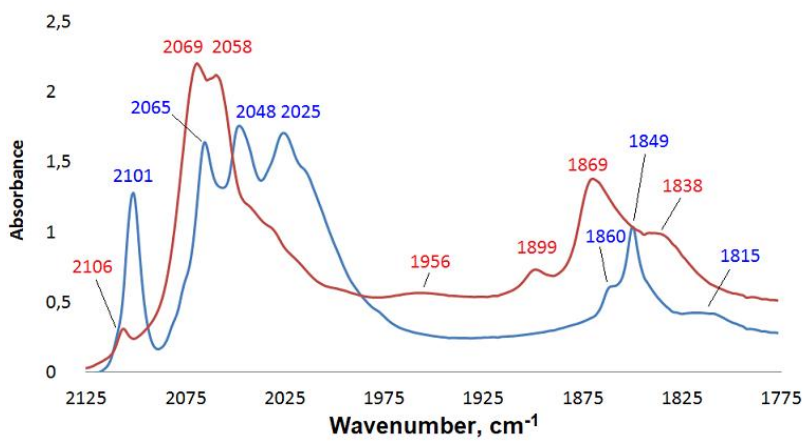

Figure 1. a) Synthesis of cobalt nanoparticles. b) STEM image and nanoparticles size distribution of Co-4. c) Representative UV-vis spectra of Co-1 to $\mathbf{C o - 4}$ and $\mathrm{Co}_{2}(\mathrm{CO})_{8}$ in toluene (all concentrations are $3.4 \cdot 10^{-4} \mathrm{M}$ ). d) Excerpt of DRIFTS spectra in the characteristic $\mathrm{CO}$ stretching region (2125-1775 $\mathrm{cm}^{-1}$ ) of $\mathrm{Co}_{2}(\mathrm{CO})_{8}$ (in red) and Co-4 (in blue).

Further characterization is provided by the overlaid DRIFT spectra of $\mathrm{Co}_{2}(\mathrm{CO})_{8}$ and $\mathbf{C o - 4}$ (the most active catalyst, see below). Fig. 1d reveals that the characteristic $v_{\mathrm{CO}}$ signals of $\mathrm{Co}_{2}(\mathrm{CO})_{8}$ at 2069 and $2058 \mathrm{~cm}^{-1}$ have disappeared and that four new signals at 2101, 2065, 2048 and $2025 \mathrm{~cm}^{-1}$, attributed to terminal carbonyl stretches, have appeared. Additional spectral changes have occurred in region $1900-1800 \mathrm{~cm}^{-1}$, where the signals of $\mathrm{Co}_{2}(\mathrm{CO})_{8}$ at 1899,1869 and $1838 \mathrm{~cm}^{-1}$ have given way for new signals at 1860,1849 and $1815 \mathrm{~cm}^{-1}$ for Co-4. Similar changes have occurred for all Co catalysts (for Co-1, Co-2 and Co-3, see Figures S7 and S8 in SI). Overall, these IR results suggest that these Co nanoparticles possess specific surface sites containing bound $\mathrm{CO}$ ligands which are different from those found in the starting precursor, $\mathrm{Co}_{2}(\mathrm{CO})_{8}$, and could be the key for catalysis. For comparison a cobalt precursor with no carbonyl ligand, $\mathrm{Co}\left(\mathrm{C}_{8} \mathrm{H}_{12}\right)\left(\mathrm{C}_{18} \mathrm{H}_{13}\right)$, was 
used to prepare Co nanoparticles using the same synthetic procedure. In this case, the Co nanoparticles were found similar in size distribution (see Fig. S5), but inactive in hydrosilylation reaction. To attribute the catalytic activity in alkene hydrosilylation exclusively to cobalt, ICP-MS (inductively coupled plasma mass spectrometry) analysis was carried out on the starting material $\left(\mathrm{Co}_{2}(\mathrm{CO})_{8}\right)$ and the most active catalyst Co-4. As expected, no Pt or traces of Pt were detected (below $0.05 \mathrm{ppm}$ of $\mathrm{Pt}$ for $\mathrm{Co}_{2}(\mathrm{CO})_{8}$ i.e. below the detection limit of the apparatus and ca. 0.04 ppm of Pt for the Co-4) which cannot account for the catalytic activity.

Table 1. The average size of Co nanoparticles

\begin{tabular}{ccccc}
\hline Catalyst & Co-1 & Co-2 & Co-3 & Co-4 \\
\hline Average size, nm & $1.6 \pm 0.2$ & $1.8 \pm 0.3$ & $1.9 \pm 0.5$ & $2.1 \pm 0.4$ \\
$\begin{array}{c}\text { Synthesis temper- } \\
\text { ature, }{ }^{\circ} \mathrm{C}\end{array}$ & 140 & 120 & 80 & 60
\end{tabular}

The obtained solutions of Co NPs were tested as catalysts in 1octene hydrosilylation using an industrially relevant tertiary silane, namely $1,1,1,3,5,5,5$-heptamethyltrisiloxane $\left(\mathrm{MD}^{\mathrm{H}} \mathrm{M}\right)$. As summarized in Table 2 (entries 1-4), we screened the effect of catalyst preparation temperature on the catalyst activity. The catalytic tests were carried out at $30^{\circ} \mathrm{C}$ with a catalyst loading of $0.2 \mathrm{~mol} \%$ and a 1:1 molar ratio of 1-octene: $\mathrm{MD}^{\mathrm{H}} \mathrm{M}$. In all cases, the reaction reached $>97 \%$ of 1 -octene conversion and gave rise exclusively to the anti-Markovnikov hydrosilylation product along with internal octene isomers. Entries 1 and 2 (Table 2) demonstrate how the high temperatures $\left(>120{ }^{\circ} \mathrm{C}\right)$ used to prepare nanoparticles Co-1 and Co-2 are detrimental for the reaction outcome with an extensive isomerization of $\mathbf{1}(95 \%)$ into internal isomers and formation of $<2 \%$ of anti-Markovnikov hydrosilylated product after $7 \mathrm{~h}$ at $30{ }^{\circ} \mathrm{C}$. Gratifyingly, lowering the temperature of the catalyst preparation to $80{ }^{\circ} \mathrm{C}(\mathbf{C o - 3})$ raised the hydrosilylation yield to $13 \%$ (entry 3), while lowering it further to $60{ }^{\circ} \mathrm{C}(\mathbf{C o}-4)$ led to a drastic improvement of the hydrosilylation reaction with a product 3a yield of $70 \%$ (entry 4). Contrary to the previous entries, where isomerization was the dominant reaction, the use of catalyst Co-4 led to substantially less internal isomers (yield < 30\%). Overall, these data show that the Co NP preparation temperature strongly influences the catalytic performances in alkene hydrosilylation reaction and therefore for the upcoming studies, Co-4 was chosen as the catalyst. On a further note, we would like to emphasize that Co-4 is the first Co-based example in the family of NP alkene hydrosilylation catalysts (currently limited to $\mathrm{Fe}, \mathrm{Pt}$ and $\mathrm{Ni})^{20,24,25}$.

Table 2. Preliminary screening of the catalytic conditions and the dependence of the nanoparticle synthesis temperature on the catalysts selectivity. ${ }^{\mathrm{a}}$

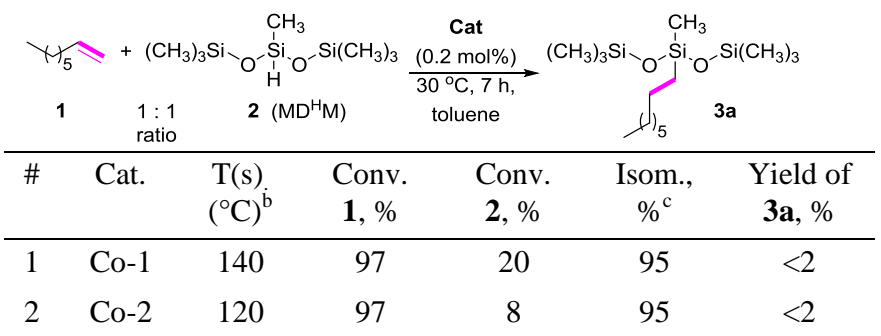

$\begin{array}{lllllll}3 & \text { Co-3 } & 80 & >99 & 13 & 85 & 13 \\ 4 & \text { Co-4 } & 60 & >99 & 70 & 29 & 70\end{array}$

[a] Conditions: 1-octene $(74 \mu \mathrm{L}, 0.47 \mathrm{mmol}, 0.825 \mathrm{M}), \mathrm{MD}^{\mathrm{H}} \mathrm{M}$ $(128 \mu \mathrm{L}, 0.47 \mathrm{mmol}, 0.825 \mathrm{M})$, mesitylene as GC standard (46 $\mu \mathrm{L})$, Co catalyst $(42 \mu \mathrm{L})$, toluene $(281 \mu \mathrm{L})$. Conversions of starting materials and formation of product are based on GC. [b] T(s) - Synthesis temperature of the cobalt NPs. [c] Isomerization (\%) corresponds to the sum of formed isomers.

With Co-4 in hand, we further studied the influence of alkene and silane concentrations on the hydrosilylation reaction outcome. When the hydrosilylation reaction is carried out with a $1: 1$ ratio of 1 -octene:silane at $0.825 \mathrm{M}$ concentration (Table 3 entry 1), $70 \%$ of hydrosilylated product, $\mathbf{3 a}$, is formed along with $29 \%$ of octene isomers. Doubling the concentration of both substrates to $1.650 \mathrm{M}$ (entry 2) leads to improved yield of $86 \%$ for product 3a. These results from entries 1 and 2 suggest that for high hydrosilylation yields the overall concentration of substrates is important. Furthermore, a two-fold excess of silane was used at $0.825 \mathrm{M}$ concentration (entry 3), which led to $70 \%$ of hydrosilylated product after $7 \mathrm{~h}$. This suggests that the impact of silane concentration is more important than that of the alkene. Doubling both starting materials concentrations leads to an increase of the yield from $70 \%$ after $7 \mathrm{~h}$ (entry 3 ) to $>95 \%$ within $3.5 \mathrm{~h}$ of reaction (entry 4 , TON 475 , TOF $135 \mathrm{~h}$ ${ }^{1}$ ), which is comparable to the state of the art results reported in the literature $(>95 \%))^{7,9,35}$ These results demonstrate that higher initial concentrations of starting materials and the use of excess of silane improves dramatically the overall yield of hydrosilylation product. However, it is worth noting that the use of a stoichiometric amount or an excess of silane is not mandatory to obtain high yields in product $\mathbf{3 a}$, as demonstrated in Table 3 entry 5 . Here, $86 \%$ yield of $\mathbf{3 a}$ is reached within $7 \mathrm{~h}$ when using excess of 1-octene with an initial concentration of $2.20 \mathrm{M}$.

To highlight the unique features of Co-4 as a NP catalyst, we compared its reactivity (entry 4) with its starting material, $\mathrm{Co}_{2}(\mathrm{CO})_{8}$, under the same experimental conditions (entry 6). The catalytic system employing $\mathrm{Co}_{2}(\mathrm{CO})_{8}$ was found much less active, reaching a maximum yield of only $36 \%$ (vs $>95 \%$ for the Co NPs). 
Table 3. Screening of the alkene/silane concentrations on the formation of hydrosilylated product 3a using cobalt catalyst Co-4. $^{\mathrm{a}}$

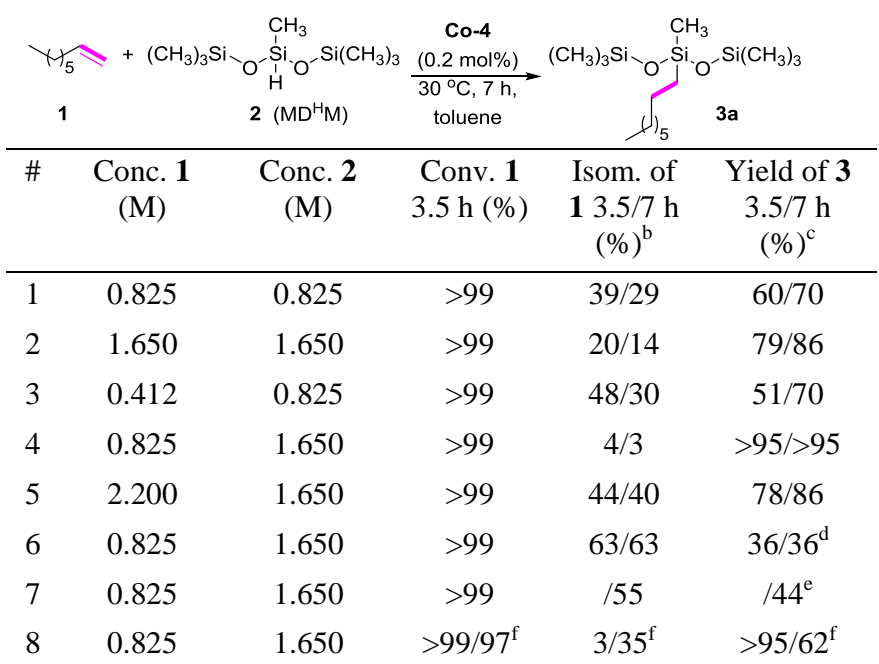

[a] Conditions: 1-octene $(37-148 \mu \mathrm{L}, 0.24-0.94 \mathrm{mmol}), \mathrm{MD}^{\mathrm{H}} \mathrm{M}$ (64-256 $\mu \mathrm{L}, 0.24-0.94 \mathrm{mmol})$, mesitylene as GC standard (26-83 $\mu \mathrm{L}), \mathbf{C o}-4(42 \mu \mathrm{L})$, toluene $(0-345 \mu \mathrm{L})$. Conversion of $\mathbf{1}$ is based on GC. [b] Isomerization of $\mathbf{1}(\%)$ corresponds to the sum of formed 1-octene isomers. [c] Formation of product is based on GC conversion of the limiting substrate. [d] $0.2 \mathrm{~mol} \%$ (per Coatom) of $\mathrm{Co}_{2}(\mathrm{CO})_{8}$ was used instead of Co-4. [e] $0.05 \mathrm{~mol} \%$ of Co-4 was used. [f] After $3.5 \mathrm{~h}, 0.47 \mathrm{mmol}$ of 1 and $0.47 \mathrm{mmol}$ of $\mathbf{2}$ were added. The conversion of $\mathbf{1}$, the yield of isomerization of $\mathbf{1}$ and the yield in product $\mathbf{3 a}$ correspond to the newly added $\mathbf{1}$ after $3.5 \mathrm{~h}$ of reaction.

Moreover, to further demonstrate the applicability of Co-4 in industrial processes, the hydrosilylation of 1-octene with $\mathrm{MD}^{\mathrm{H}} \mathrm{M}$ was carried out with only $0.05 \mathrm{~mol} \%$ catalyst loading to give $44 \%$ of hydrosilylation product after $7 \mathrm{~h}$ (entry 7 , TON 880 , TOF $125 \mathrm{~h}^{-1}$ ). Thus, when used with an appropriate concentration of silane to prevent octene isomerization, this Co-4 system was found very active and selective whatever the olefin:silane ratio. Furthermore, it is worth pointing out that throughout the reaction a tandem isomerizationhydrosilylation reaction occurs, that allows the conversion of internal octene isomers into 1-octene (as shown by the decrease of isomerization yield in Table 3) and further hydrosilylation of the latter. Finally, the reusability of our catalytic system was studied. As Co-4 is composed of very small Co NPs in solution, its separation from the products would be very difficult, requiring a multistep procedure to precipitate, wash and re-disperse the NPs. We therefore decided to test its reusability by adding a new batch of substrates $(0.47 \mathrm{mmol}$ of 1 and $0.47 \mathrm{mmol}$ of $\mathbf{2}$ ) on top of the spent catalyst in solution (entry 8 Table 3 ). After $3.5 \mathrm{~h}$ of reaction, a quasi-complete conversion of 1 (97\%) was observed and 62\% yield of product $\mathbf{3}$ was reached, showing that the catalyst is still active and can be successfully re-used. However, one can notice an increased proportion of internal octene isomers (36\%) with respect to that observed (3\%) after addition of substrates on the fresh catalyst.

Based on these results, we decided to use the reaction conditions of entry 4 for the following alkene scope tests, which are summarized in Scheme 1. Moving from 1-octene to the corresponding cyclic analogue, vinylcyclohexane, we obtained the
anti-Markovnikov product $\mathbf{3 b}$ in $71 \%$ yield after $3.5 \mathrm{~h}$ of reaction alongside isomers $(<30 \%)$ of the starting material (Scheme 1, entry 1). However, when simple non-isomerizable terminal alkenes such as styrene and tert-butylethylene (TBE) were used at $30{ }^{\circ} \mathrm{C}$ with $\mathrm{MD}^{\mathrm{H}} \mathrm{M}$, we obtained rather poor $16 \%$ and $42 \%$ yields of respective hydrosilylated products $3 \mathbf{c}$ and 3d. In contrast, excellent results were obtained with the bulky heptamethyl-3-vinyltrisiloxane $\left(\mathrm{MD}^{\mathrm{Vi}} \mathrm{M}\right)$ substrate, which reacted quantitatively with $\mathrm{MD}^{\mathrm{H}} \mathrm{M}$ yielding exclusively the hydrosilylated product $\mathbf{3 e}$.

Next, we turned our interest to allyl group containing substrates, which are known to be notoriously difficult to selectively hydrosilylate as competing alkene isomerization ${ }^{36}$ and C $-\mathrm{O}$ cleavage for allyl ethers ${ }^{37-39}$ is frequently observed. Gratifyingly, hydrosilylation of allyloxytrimethylsilane leads to $86 \%$ of the expected hydrosilylation product $\mathbf{3 f}$ along with a small amount of alkene isomerization (14\%). When benzyl allyl ether is used, $75 \%$ of expected product $3 \mathbf{g}$ is formed alongside with $24 \%$ of internal alkene isomers. The same high reactivity was not however seen with allyl acetate, which led to a meagre $21 \%$ yield of expected product $\mathbf{3 h}$. Interestingly, when the alkene functionality is further away from the ester group, such as in ethyl-4-pentenoate, the reaction afforded the hydrosilylated product $3 \mathbf{3 i}$ in excellent yield $(88 \%)$. To further demonstrate the applicability of this $\mathbf{C o - 4}$ catalyst with industrially relevant substrates, we carried out the hydrosilylation of allyl glycidyl ether with $\mathrm{MD}^{\mathrm{H}} \mathrm{M}$. As shown in Scheme 1, the Co-4 nanoparticles are highly reactive and selective towards the hydrosilylation of the allyl group, leading to the hydrosilylation product $\mathbf{3 j}$ in quantitative yield with no detectable $\mathrm{C}=\mathrm{C}$ bond isomerization.

While most of the examples have led to the expected antiMarkovnikov products in excellent yields, three substrates (styrene, TBE and allyl acetate) were found problematic. One option to enhance the reactivity of Co-4 catalyst would be to vacate a binding site on the catalyst surface. For carbonyl containing species, this strategy was tested in 1980 by Wrighton's group when they activated $\mathrm{Et}_{3} \mathrm{SiCo}(\mathrm{CO})_{4}$ towards the hydrosilylation of 1-pentene with $\mathrm{Et}_{3} \mathrm{SiH}$ under UV irradiation. ${ }^{40}$ More recently the beneficial effect of UV light on the reaction outcome has been demonstrated on iron $^{41}$ and manganese $\mathrm{e}^{41,42}$ catalysts containing bound $\mathrm{CO}$ ligands in the reduction of aldehydes, ketones and carboxylic acids with silanes. It is also worth noting that hydrosilylation of amides was also found possible using $\mathrm{Co} 2(\mathrm{CO})_{8}$ under UV irradiation or thermal conditions $\left(100^{\circ} \mathrm{C}\right) .^{43}$ We therefore carried out the same reactions under UV irradiation $(>250 \mathrm{~nm})$ using $300 \mathrm{~W}$ Asahi Spectra Xenon Lamp (Max303) instrument (results in blue in Scheme 1). The beneficial effect of UV irradiation is most clearly seen with styrene, where the $16 \%$ yield of $\mathbf{3 c}$ obtained under thermal reaction conditions has rocketed to 90\% under UV irradiation. Moreover, TBE has demonstrated a drastic yield increase for $3 \mathbf{d}$ from $42 \%$ under thermal conditions to $73 \%$ after $3.5 \mathrm{~h}$ of UV irradiation. For all other entries in Table 1, comparable or higher yields under UV conditions were achieved (except for $\mathbf{3 g}$ ). Additionally, it is worth emphasizing the fact that six out of the nine hydrosilylation products shown in Scheme 1 have never been reported with nonprecious metal catalysts, therefore demonstrating the wide potential of using this specific Co-4 catalyst in alkene hydrosilylation with industrially relevant $\mathrm{MD}^{\mathrm{H}} \mathrm{M}$ under thermal and UV conditions. Our current explanation for this impressive increase of hydrosilylation yield under UV irradiation is that UV irradiation allows the decoordination of $\mathrm{CO}$ ligands 
at the surface of the NPs that liberates specific active sites responsible for hydrosilylation (as known with metal carbonyl complexes) and/or help to decoordinate the substrate or product from the NPs surface.

Scheme 1. Co-4 catalyzed hydrosilylation of various terminal alkenes with $\mathrm{MD}^{\mathrm{H}} \mathrm{M}^{\mathrm{a}}$

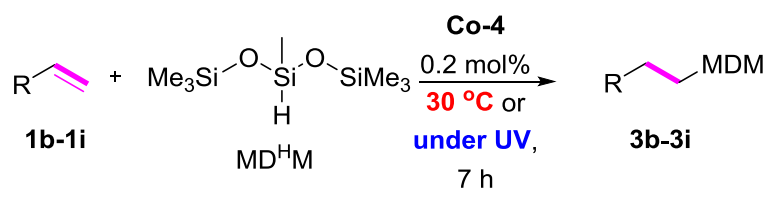

\begin{tabular}{lccc}
\hline Products & $\begin{array}{c}\text { GC yield } \\
\text { at } 30^{\circ} \mathrm{C}(\%)^{\mathrm{b}}\end{array}$ & $\begin{array}{c}\text { GC yield } \\
\text { under UV }(\%)^{\mathrm{b}}\end{array}$ & $\begin{array}{c}\text { State of } \\
\text { the } \text { art }^{\mathrm{c}}\end{array}$ \\
\hline
\end{tabular}

$\overbrace{3 \mathbf{b}}^{\mathrm{MDM}} \quad{71^{\mathrm{d}}[28]}^{\mathrm{9}} \mathbf{0}^{\mathrm{d}}(82)[10] \quad$ n.r<smiles>CCCc1ccccc1</smiles>

16<smiles>COCCC(C)(C)C</smiles>
3d<smiles>CO[SiH2]O[Si](C)(CC[N+]([O-])O[SiH3])O[SiH3]</smiles><smiles>C[Mg]O[Si](C)(C)CCCC[Mg]</smiles>
$86^{\mathrm{d}}(82)[10]$ $80^{\mathrm{d}}[15]$ $55^{\mathrm{d}}[44]$ n.r<smiles>[Nb]CCC[Se]OCc1ccccc1</smiles>
$75^{\mathrm{d}}(65)[24]$ $21[\mathrm{n} . \mathrm{d}]$

$\begin{array}{lr}21^{d}(12)[n \cdot d] & n \cdot r \\ >99(93) & n \cdot r \\ >99^{d}(95) & n \cdot r\end{array}$

[a] Conditions: alkene $(0.47 \mathrm{mmol}, 0.82 \mathrm{M}, 1 \mathrm{eq}), \mathrm{MD}^{\mathrm{H}} \mathrm{M}(256$ $\mu \mathrm{L}, 0.94 \mathrm{mmol}, 1.650 \mathrm{M}, 2 \mathrm{eq})$, mesitylene as GC standard (46 $\mu \mathrm{L})$, Co-4 (0.92 $\mu \mathrm{mol}, 0.2 \mathrm{~mol} \%)$, toluene $(91-171 \mu \mathrm{L}) . \mathrm{Bn}-$ benzyl. [b] The yield in brackets refers to the isolated yield, while the yield in square brackets refers to the sum of alkene isomers by the end of reaction time. $n$. $d$ - not detected. [c] State of the art examples correspond to the highest yield of corresponding hydrosilylation product catalyzed by non-precious metal complexes. n.r - not reported. [d] No change in yield after $3.5 \mathrm{~h}$ of reaction time.

Finally, to further clarify the versatility of the present catalytic system, other challenging substrates containing cyano and amido groups (3-pentenenitrile, predominantly as the trans isomer, and N,N-dimethylacrylamide) and geminal-alkenes ( $\alpha$ methylstyrene) were also tested. Unfortunately, hydrosilylation did not proceed with 3-pentenenitrile and N,Ndimethylacrylamide and only $3 \%$ of hydrosilylated product was detected with $\alpha$-methylstyrene, under thermal and UV conditions.

As demonstrated by the results from Table 3, Co-4 can promote tandem isomerization-hydrosilylation of internal alkenes formed during the reaction. Taking advantage of such results, we decided to study the possibility to transform otherwise inactive internal alkenes into anti-Markovnikov hydrosilylation products through tandem isomerizationhydrosilylation reaction. Currently there are only few examples reporting non noble metal systems capable of performing the tandem isomerization-hydrosilylation of internal hexenes or octenes with pentamethyldisiloxane, $(\mathrm{MeO})_{3} \mathrm{SiH}$, $(\mathrm{EtO})_{3} \mathrm{SiH}, \quad \mathrm{Et}_{2} \mathrm{SiH}_{2} \quad \mathrm{Ph}_{2} \mathrm{SiH}$ and $\mathrm{PhSiH}_{3}$ in $61-97 \%$ yields. ${ }^{16,21,25,44-46}$ The present Co-4 catalyst was first tested in the hydrosilylation of 2-trans-octene, 1-methyl-1-cyclohexene and methyl oleate under standard thermal conditions at $30^{\circ} \mathrm{C}$, but no hydrosilylated products were detected. However, when the samples were left under UV-irradiation $(\lambda>250 \mathrm{~nm})$, the efficient isomerization of the internal $\mathrm{C}=\mathrm{C}$ bond occurred, giving rise to the terminal alkylsilane products (Scheme 2). 2 trans-octene demonstrated the fastest tandem isomerizationhydrosilylation reaction as after $3.5 \mathrm{~h}$ of UV irradiation, $>99 \%$ of the starting material was selectively converted into the linear alkylsilane 3a (Scheme 2a). Alternatively, the tandem isomerization-hydrosilylation reaction can be carried out using higher wavelength UV light. For example, when the same reaction mixture was irradiated with $>300 \mathrm{~nm}$ and $>350 \mathrm{~nm}$ UV light, yields of 3a were $89 \%$ and $86 \%$ respectively, demonstrating the possibility of using more affordable lower energy light sources. Similar tandem isomerizationhydrosilylation of 2-trans-octene with $\mathrm{MD}^{\mathrm{H}} \mathrm{M}$ was carried out by Sunada et al. but at much higher temperature $\left(80^{\circ} \mathrm{C}\right)$ and using significantly higher catalyst loadings $(3 \mathrm{~mol} \%)$ of a $\mathrm{Fe}-$ complex to obtain the same linear product $\mathbf{3 a}$ in $82 \%$ yield. $^{47}$ To further demonstrate the versatility of this Co-4 catalytic system in tandem isomerization-hydrosilylation of internal alkenes, we chose 1-methyl-1-cyclohexene as a more challenging substrate. Irradiating 1-methyl-1-cyclohexene together with $\mathrm{MD}^{\mathrm{H}} \mathrm{M}$ in the presence of $0.2 \mathrm{~mol} \%$ of $\mathbf{C o - 4}$ led to $35 \%$ of exocyclic alkylsilane product $3 \mathbf{k}$ after $16 \mathrm{~h}$ of UV irradiation (Scheme 2b). While the latter two internal alkenes were successfully hydrosilylated to their corresponding linear products, they were lacking additional functional groups which could offer further options for functionalization. In light of the possibility to utilize otherwise inert internal alkenes for the exclusive chemoselective synthesis of anti-Markovnikov products, we tested if unsaturated fatty ester derivatives containing two types of functionalities could be selectively hydrosilylated. Note that this reaction was never reported as such using directly unprotected fatty esters and a non-noble metal catalyst. The only example from $\mathrm{Hu}$ 's group demonstrated the tandem isomerization-hydrosilylation of TBSprotected oleyl alcohol (TBS - tert-butyldimethylsilyl) with $(\mathrm{EtO})_{3} \mathrm{SiH}$ using $10 \mathrm{~mol} \%$ of Ni-catalyst. While reasonable $45 \%$ yield of linear product was obtained after $24 \mathrm{~h}$, the reaction was plagued by low selectivity, as both the hydrosilylation and dehydrogenative silylation products were obtained and the protection of the functional group was needed. $^{25}$ 
Scheme 2. Co-4 catalyzed tandem isomerizationhydrosilylation of internal alkenes under UV irradiation. ${ }^{2}$
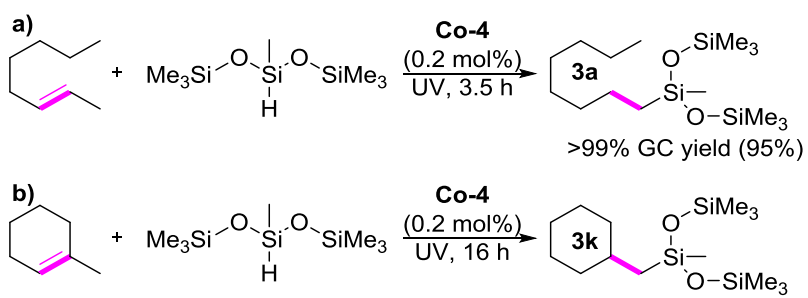

$35 \%$ GC yield $(22 \%)$

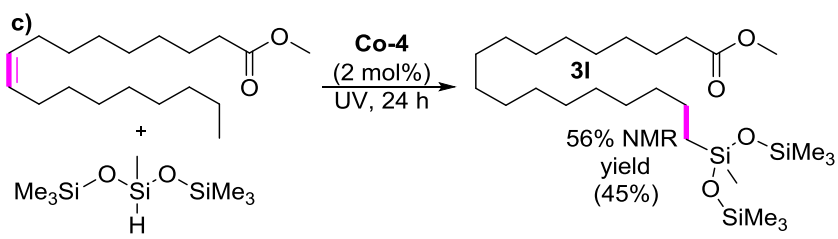

[a] Conditions: alkene $(0.47 \mathrm{mmol}, 1 \mathrm{eq}), \mathrm{MD}^{\mathrm{H}} \mathrm{M}(256 \mu \mathrm{L}$, 0.94 mmol, 2 eq), mesitylene as GC/NMR standard (46 $\mu \mathrm{L}), \mathbf{C o}-4$ $(0.92 \mu \mathrm{mol}$ or $9.24 \mu \mathrm{mol}, 0.2$ or $2.0 \mathrm{~mol} \%)$, toluene $(0-171 \mu \mathrm{L})$. Irradiation was carried out at room temperature and no major temperature increase (up to $45^{\circ} \mathrm{C}$ ) was observed under irradiation. Formation of products are based on GC for $a$ ) and b), and on ${ }^{1} \mathrm{H}$ NMR for $\mathrm{c}$ ). The yield in brackets refers to the isolated yield.

Contrary to this literature example, the present system was able to isomerize unprotected methyl oleate to terminal C18:1 fatty ester and gave rise to the linear hydrosilylated product $\mathbf{3 l}$ (along with internal isomers of methyl oleate) in good yield $(56 \%)$ after $24 \mathrm{~h}$ of UV irradiation using $2 \mathrm{~mol} \%$ of the Co-4 catalyst (Scheme 2c). It is worth noting here that the starting $\mathrm{Co}_{2}(\mathrm{CO})_{8}$ used in the exact same conditions was completely inactive. We hope this remarkable Co-4 catalyst will inspire further research into the valorization of renewable unsaturated fatty acid derivatives using such non precious-metal catalysts.

\section{Conclusion}

We have developed here a remarkable noble-metal free catalytic system based on very small cobalt nanoparticles. These NPs are prepared via an easy procedure (low temperature, no surfactant, no high boiling point solvents) with readily accessible starting materials $\left(\mathrm{Co}_{2} \mathrm{CO}_{8}\right.$ and $n$-octylsilane). The hydrosilylation results using various Co NPs catalysts demonstrated the important role of the catalyst preparation temperature and the concentrations of alkene and $\mathrm{MD}^{\mathrm{H}} \mathrm{M}$ to reach very high conversion and yields. The best catalytic system was found capable of hydrosilylating various alkenes with nonactivated industrially relevant $\mathrm{MD}^{\mathrm{H}} \mathrm{M}$ at low temperature $\left(30{ }^{\circ} \mathrm{C}\right)$ with or without UV irradiation and with effective catalyst loading at $0.2 \mathrm{~mol} \%$. In all cases, a selectivity towards the exclusive anti-Markovnikov hydrosilylation product was observed with yields up to $>99 \%$. Furthermore, these cobalt nanoparticles were also found to catalyze the tandem isomerization-hydrosilylation of internal alkenes such as 2-transoctene and 1-methyl-1-cyclohexene under UV irradiation. Finally, as a more challenging substrate we also reported here the unique tandem isomerization-hydrosilylation of unprotected fatty ester (methyl oleate), leading exclusively to the linear silylated product.

\section{Experimental Section}

General Methods. Unless otherwise noted, all reactions were conducted in oven-dried vials with a magnetic stir bar under an argon atmosphere. Toluene and mesitylene were distilled from sodium benzophenone ketyl radical and stored under argon in a glovebox. $\mathrm{Co}_{2}(\mathrm{CO})_{8}$ was used as received and stored under argon in a glovebox freezer at $-40{ }^{\circ} \mathrm{C}$. Methyl oleate (from Nu-Check Prep, Inc) was degassed by freezepump-thaw cycles, stored for $4 \mathrm{~h}$ over Selexsorb® $\mathrm{CD}$ and then stirred for 3 days with activated alumina. Various alkenes were first passed through short plug of silica, degassed by freeze-pump-thaw cycles and used without further purification. Short plug column chromatography was performed with Macherey-Nagel Silica $60 \mathrm{M}$ silica gel $(0.04-0.063 \mathrm{~mm}) .{ }^{1} \mathrm{H}$, ${ }^{13} \mathrm{C}\left\{{ }^{1} \mathrm{H}\right\},{ }^{29} \mathrm{Si}\left\{{ }^{1} \mathrm{H}\right\}$ NMR, HSQC and HMBC spectra were recorder on Bruker AC $300 \mathrm{MHz}$ instrument. Chemical shifts $(\delta)$ are given in parts per million ( $\mathrm{ppm})$ referenced to the appropriate solvent peak $\left({ }^{1} \mathrm{H}\right.$ NMR: $\mathrm{CDCl}_{3}$ at $7.26 \mathrm{ppm}, \mathrm{CD}_{2} \mathrm{Cl}_{2}$ at $5.32 \mathrm{ppm} .{ }^{13} \mathrm{C} \mathrm{NMR:} \mathrm{CDCl}_{3}$ at $77.16 \mathrm{ppm}, \mathrm{CD}_{2} \mathrm{Cl}_{2}$ at 53.84 $\mathrm{ppm})$. The data are reported as follows: chemical shift (ppm), multiplicity $(\mathrm{s}=$ singlet, $\mathrm{t}=$ triplet, $\mathrm{p}=$ pentet, $\mathrm{dd}=$ doublet of doublets, dddd $=$ doublet of doublet of doublet of doublets, nfom $=$ non-first order multiplet, br. $\mathrm{s}=$ broad singlet, br. $\mathrm{m}=$ broad multiplet, $\mathrm{m}=$ multiplet), coupling constant $\mathrm{J}(\mathrm{Hz})$ and integration. Structural assignments were made with additional information from gHSQC and gHMBC experiments. High resolution mass spectra were measured on a Bruker QTOF Impact II at Centre Commun de Spectrométrie de Masse. Diffuse Reflectance Infrared Fourier Transform Spectroscopy (DRIFTS) spectra of solid compounds were collected from a Thermo Scientific Nicolet 6700 FT-IR spectrometer equipped with an MCT detector (64 scans, resolution $2 \mathrm{~cm}^{-1}, 298 \mathrm{~K}$ ). The reported spectra are presented in a Kubelka-Munk format. Transmission Electron Microscopy (TEM) of the cobalt colloids was performed at the "Centre Technologique des Microstructures", University Lyon 1, Villeurbanne, France, with a JEOL2100F transmission electron microscope, using an acceleration voltage of $200 \mathrm{kV}$ under inert conditions. The samples were prepared by depositing a drop of colloidal solution on a copper grid covered by a carbon film and letting it dry. Inductively coupled plasma mass spectrometry (ICP-MS) analysis was carried out by Mikroanalytisches Labor Pascher (Germany) on $\left(\mathrm{Co}_{2}(\mathrm{CO})_{8}\right)$ and on Co-4.Gas chromatography analysis was performed on HP 6890 chromatograph with a HP5 (5\% of phenylmethylsiloxane) column (30 m length, $320 \mu \mathrm{m}$ of diameter, $0.25 \mathrm{~nm}$ of thickness) equipped with flame ionization detector (FID). Throughout the study mesitylene was used as GC internal standard to obtain the GC yield for products 3a3k. For all of the UV experiments Asahi Spectra Xenon Light Source $300 \mathrm{~W}$ (Max303) instrument was used without any filters, unless stated otherwise. The wavelength of the light is ca. 250-420 $\mathrm{nm}$ and the reaction mixture can warm up to 45 ${ }^{\circ} \mathrm{C}$ during the irradiation. At the end of thermal or UV reaction the mixture was passed through short plug of silica (pentane was used as eluent) to remove catalyst and volatiles (remaining starting materials) were removed under reduced pressure at $50{ }^{\circ} \mathrm{C}$ to give clear liquid product.

Preparation of Co-NP catalysts (Co-1, Co-2, Co-3, Co-4). A dry $300 \mathrm{~mL}$ Fisher-Porter reaction vessel was charged in a glovebox with $\mathrm{Co}_{2}(\mathrm{CO})_{8}(188 \mathrm{mg}, 0.55 \mathrm{mmol}), 50 \mathrm{~mL}$ of toluene and $n$-octylsilane $(16 \mu \mathrm{L}, 7.5 \mathrm{~mol} \%$ compared to $\mathrm{Co}-$ atom). The solution was quickly degassed to remove argon, then put under $\mathrm{H}_{2}$ (4 bars) atmosphere, and stirred at corresponding temperature $\left(60{ }^{\circ} \mathrm{C}, 80^{\circ} \mathrm{C}, 120^{\circ} \mathrm{C}\right.$ or $\left.140{ }^{\circ} \mathrm{C}\right)$ for 24 h. The solution was then left to cool down to room tempera- 
ture, depressurized and stored under argon in a Schlenk flask. The resulting brownish to light red solutions contained 22 $\mu \mathrm{mol} / \mathrm{mL}$ of cobalt and could be stored at room temperature or at $-40{ }^{\circ} \mathrm{C}$ under inert atmosphere without noticeable loss of activity after several months.

General procedure for alkene hydrosilylation with $\mathbf{M D}^{\mathbf{H}} \mathbf{M}$. In an argon filled glovebox, a $4 \mathrm{~mL}$ vial was charged with the appropriate alkene $(0.47 \mathrm{mmol}, 1 \mathrm{eq}), \mathrm{MD}^{\mathrm{H}} \mathrm{M}(256 \mu \mathrm{L}, 0.94$ mmol, 2 eq), mesitylene ( $46 \mu \mathrm{L}, 0.6 \mathrm{mmol}$, GC standard), Co4 catalyst $(42 \mu \mathrm{L}, 0.93 \mu \mathrm{mol}, 0.2 \mathrm{~mol} \%)$ and a stirring bar. The reaction volume was adjusted by adding corresponding amount of toluene to reach total volume of $571 \mu \mathrm{L}$. The reaction mixture was stirred for the indicated time at $30^{\circ}$ (oil bath temperature) and quenched with wet pentane for GC experiment (ca. $0.5 \mathrm{~mL}$ ). For reactions conducted under UV irradiation the vials were placed against the collimator and wrapped with aluminum foil for the duration of the reaction.

Gram scale alkene hydrosilylation with $\mathbf{M D}^{\mathrm{H}} \mathbf{M}$. In similar fashion to the general procedure, the mixture of 1-octene (592 $\mu \mathrm{L}, 3.77 \mathrm{mmol}, 1 \mathrm{eq}), \mathrm{MD}^{\mathrm{H}} \mathrm{M}(2048 \mu \mathrm{L}, 7.54 \mathrm{mmol}, 2 \mathrm{eq})$, mesitylene ( $368 \mu \mathrm{L}, 2.65 \mathrm{mmol}$, GC standard), Co-4 catalyst (336 $\mu \mathrm{L}, 7.44 \mu \mathrm{mol}, 0.2 \mathrm{~mol} \%)$ and toluene $(1224 \mu \mathrm{L})$ gave rise to hydrosilylation product $3 \mathbf{a}(>98 \%$ GC yield after $3.5 \mathrm{~h})$ in $94 \%$ isolated yield (1187 $\mathrm{mg}, 3.55 \mathrm{mmol})$.

Procedures for internal alkene hydrosilylation with MD $^{\mathbf{H}}$ M. a) In an argon filled glovebox, a $4 \mathrm{~mL}$ vial was charged with 2-trans-octene (74 $\mu \mathrm{L}, 0.47 \mathrm{mmol}, 1$ eq), $\mathrm{MD}^{\mathrm{H}} \mathrm{M}$ (256 $\mu \mathrm{L}, 0.94 \mathrm{mmol}, 2 \mathrm{eq})$, mesitylene ( $46 \mu \mathrm{L}, 0.6 \mathrm{mmol})$, Co4 catalyst $(42 \mu \mathrm{L}, 0.2 \mathrm{~mol} \%)$, toluene $(153 \mu \mathrm{L})$ and a stirring bar.

b) In an argon filled glovebox, a $4 \mathrm{~mL}$ vial was charged with 1-methyl-1-cyclohexene ( $56 \mu \mathrm{L}, 0.47 \mathrm{mmol}, 1 \mathrm{eq}), \mathrm{MD}^{\mathrm{H}} \mathrm{M}$ ( $256 \mu \mathrm{L}, 0.94 \mathrm{mmol}, 2 \mathrm{eq})$, mesitylene ( $46 \mu \mathrm{L}, 0.6 \mathrm{mmol})$, Co4 catalyst $(42 \mu \mathrm{L}, 0.2 \mathrm{~mol} \%)$, toluene $(171 \mu \mathrm{L})$ and a stirring bar.

c) In an argon filled glovebox, a $4 \mathrm{~mL}$ vial was charged with methyl oleate $(160 \mu \mathrm{L}, 0.47 \mathrm{mmol}, 1 \mathrm{eq}), \mathrm{MD}^{\mathrm{H}} \mathrm{M}(256 \mu \mathrm{L}$, $0.94 \mathrm{mmol}, 2 \mathrm{eq})$, mesitylene $(46 \mu \mathrm{L}, 0.6 \mathrm{mmol}), \mathrm{Co}-4$ catalyst $(420 \mu \mathrm{L}, 2.0 \mathrm{~mol} \%)$ and a stirring bar. The catalytic reaction was monitored by ${ }^{1} \mathrm{H}$ NMR using mesitylene as internal standard. For comparison $2.0 \mathrm{~mol} \%$ (per Co-atom) of $\mathrm{Co}_{2}(\mathrm{CO})_{8}$ was used as the catalyst for the same reaction, but no formation of $\mathbf{3 1}$ was detected.

All the samples were covered with aluminum foil and left stirring for corresponding time under UV irradiation (>250 $\mathrm{nm})$.

Synthesis of 1,1,1,3,5,5,5-heptamethyl-3-octyltrisiloxane (3a). The title compound 3a was obtained as a colorless liquid (147 $\mathrm{mg})$ in $93 \%$ isolated yield. ${ }^{1} \mathrm{H} \mathrm{NMR}\left(300 \mathrm{MHz}, \mathrm{CDCl}_{3}\right): \delta=$ 1.34-1.24 (br. m, 12H), 0.88 (t, J $6.6 \mathrm{~Hz}, 3 \mathrm{H}), 0.48-0.42$ (nfom, 2H), 0.09 (s, 18H), -0.01 (s, 3H). The spectroscopic data correspond to the reported data. ${ }^{48}$

Synthesis of 1,1,1,3,5,5,5-heptamethyl-3-(2cyclohexylethyl)trisiloxane $(\mathbf{3 b})$. The title compound $\mathbf{3 b}$ was obtained as a colorless liquid (128 mg) in $82 \%$ isolated yield. ${ }^{1} \mathrm{H}$ NMR $\left(300 \mathrm{MHz}, \mathrm{CDCl}_{3}\right): \delta=1.78-1.61(\mathrm{~m}, 5 \mathrm{H}), 1.30-1.06$ (m, 6H), 0.90-0.79 (m, 2H), 0.45 (nfom, 2H), $0.09(\mathrm{~s}, 18 \mathrm{H})$, 0.00 (s, 3H). ${ }^{13} \mathrm{C}\left\{{ }^{1} \mathrm{H}\right\}$ NMR $\left(75 \mathrm{MHz}, \mathrm{CDCl}_{3}\right): \delta=40.5,33.2$, 30.8, 27.0, 26.7, 14.7, 2.0, -0.2. ${ }^{29} \mathrm{Si}\left\{{ }^{1} \mathrm{H}\right\}$ NMR $(60 \mathrm{MHz}$, CDCl3): $\delta=6.8,-20.6$. HRMS (ESI+) m/z: $[\mathrm{M}+\mathrm{Na}]^{+}$Calcd for $\mathrm{C}_{15} \mathrm{H}_{36} \mathrm{Si}_{3} \mathrm{O}_{2} \mathrm{Na}$ 355.1915, Found 355.1920; [M+H] ${ }^{+}$Calcd for $\mathrm{C}_{15} \mathrm{H}_{37} \mathrm{Si}_{3} \mathrm{O}_{2}$ 333.2096, Found 333.2102.
Synthesis of 1,1,1,3,5,5,5-Heptamethyl-3-phenethyltrisiloxane $(\mathbf{3} \boldsymbol{c})$. The title compound $\mathbf{3 c}$ was obtained as a colorless liquid $(123 \mathrm{mg})$ in $82 \%$ isolated yield. ${ }^{1} \mathrm{H}$ NMR $\left(300 \mathrm{MHz}, \mathrm{CDCl}_{3}\right)$ : $\delta=7.34-7.28(\mathrm{~m}, 2 \mathrm{H}), 7.25-7.16(\mathrm{~m}, 3 \mathrm{H}), 2.71-2.63$ (nfom, 2H), 0.90-0.82 (nfom, 2H), 0.14 (s, 18H), 0.06 (s, 3H). The spectroscopic data correspond to the reported data. ${ }^{49}$

Synthesis of 1,1,1,3,5,5,5-heptamethyl-3-(3,3dimethylbutyl)trisiloxane $(\mathbf{3 d})$. The title compound $\mathbf{3 d}$ was obtained as a colorless liquid (74 $\mathrm{mg}$ ) in $51 \%$ isolated yield. ${ }^{1} \mathrm{H} \mathrm{NMR}\left(300 \mathrm{MHz}, \mathrm{CDCl}_{3}\right.$ ): $\delta=1.17$ (nfom, 2H), 0.85 (s, $9 \mathrm{H}), 0.38$ (nfom, $2 \mathrm{H}), 0.09$ (s, 18H), 0.00 (s, 3H). The spectroscopic data correspond to the reported data. ${ }^{48}$

Synthesis of 1,2-di(1,1,1,3,5,5,5heptamethyltrisiloxanyl)ethane (3e). The title compound $\mathbf{3 e}$ was obtained as a colorless liquid $(212 \mathrm{mg})$ in $95 \%$ isolated yield. ${ }^{1} \mathrm{H} \mathrm{NMR}\left(300 \mathrm{MHz}, \mathrm{CDCl}_{3}\right.$ ): $\delta=0.35$ (s, 4H, H3), 0.09 $(\mathrm{s}, 36 \mathrm{H}, \mathrm{H} 1), 0.00(\mathrm{~s}, 6 \mathrm{H}, \mathrm{H} 2)$. The spectroscopic data correspond to the reported data. ${ }^{13}$

Synthesis of 1,1,1,3,5,5,5-heptamethyl-3-(3(trimethylsilyloxy)propyl)trisiloxane (3f). The title compound 3f was obtained as a colorless liquid $(136 \mathrm{mg})$ in $82 \%$ isolated yield. ${ }^{1} \mathrm{H}$ NMR (300 MHz, $\mathrm{CDCl}_{3}$ ): $\delta=3.50$ (br. s, $2 \mathrm{H}$ ), 1.52 (br. s, 2H), 0.42 (br. s, $2 \mathrm{H}$ ), 0.23 to -0.09 (br. s, 30H). ${ }^{13} \mathrm{C}\left\{{ }^{1} \mathrm{H}\right\}$ NMR $\left(75 \mathrm{MHz}, \mathrm{CDCl}_{3}\right): \delta=65.6,26.8,13.7,1.9,-0.25,-0.3$. ${ }^{29} \mathrm{Si}\left\{{ }^{1} \mathrm{H}\right\}$ NMR $(60 \mathrm{MHz}, \mathrm{CDCl} 3): \delta=16.2,7.2,-21.2$. HRMS (ESI+) $\mathrm{m} / \mathrm{z}:[\mathrm{M}+\mathrm{Na}]^{+}$Calcd for $\mathrm{C}_{13} \mathrm{H}_{36} \mathrm{Si}_{4} \mathrm{O}_{3} \mathrm{Na} 375.1634$, Found 375.1628 .

Synthesis of 1,1,1,3,5,5,5-heptamethyl-3-(3-(benzyloxy)propyl) trisiloxane $(\mathbf{3 g})$. The title compound $\mathbf{3 g}$ was obtained as a pale yellow liquid $(114 \mathrm{mg})$ in $65 \%$ isolated yield. ${ }^{1} \mathrm{H}$ NMR (300 $\left.\mathrm{MHz}, \mathrm{CDCl}_{3}\right): \delta=7.26-7-16(\mathrm{~m}, 5 \mathrm{H}), 4,42(\mathrm{~s}, 2 \mathrm{H}), 3.34(\mathrm{t}, \mathrm{J}$ $7.0 \mathrm{~Hz}, 2 \mathrm{H}), 1.56(\mathrm{~m}, 2 \mathrm{H}), 0.39$ (nfom, 2H), 0.00 (s, 18H), $0.08(\mathrm{~s}, 3 \mathrm{H}) .{ }^{13} \mathrm{C}\left\{{ }^{1} \mathrm{H}\right\}$ NMR $\left(75 \mathrm{MHz}, \mathrm{CDCl}_{3}\right): \delta=138.9$, 128.5, 127.8, 127.6, 73.2, 72.9, 23.5, 13.8, 2.0, -0.2. ${ }^{29} \mathrm{Si}\left\{{ }^{1} \mathrm{H}\right\}$ NMR (60 MHz, CDCl3): $\delta=7.2,-21.6$. HRMS (ESI+) m/z: $[\mathrm{M}+\mathrm{Na}]^{+}$Calcd for $\mathrm{C}_{17} \mathrm{H}_{34} \mathrm{Si}_{3} \mathrm{O}_{3} \mathrm{Na}$ 393.1708, Found 393.1712.

Synthesis of 1,1,1,3,5,5,5-heptamethyl-3-(3acetoxypropyl)trisiloxane (3h). The title compound $\mathbf{3 h}$ was obtained as a colorless liquid (19 $\mathrm{mg})$ in $12 \%$ isolated yield. ${ }^{1} \mathrm{H}$ NMR (300 MHz, $\left.\mathrm{CDCl}_{3}\right): \delta=3.92(\mathrm{t}, J 6.9 \mathrm{~Hz}, 2 \mathrm{H}), 1.96$ (s, 3H), 1.59-1.49 (nfom, 2H), 0.40-0.35 (nfom, 2H), 0.00 (s, $18 \mathrm{H}),-0.07(\mathrm{~s}, 3 \mathrm{H})$. The spectroscopic data is in agreement with the reported data measured in $\mathrm{C}_{6} \mathrm{D}_{6} \cdot{ }^{50}{ }^{13} \mathrm{C}\left\{{ }^{1} \mathrm{H}\right\}$ NMR $(75$ $\left.\mathrm{MHz}, \mathrm{CDCl}_{3}\right): \delta=171.3,67.0,22.6,21.2,13.6,2.0,-0.3$. ${ }^{29} \mathrm{Si}\left\{{ }^{1} \mathrm{H}\right\}$ NMR $(60 \mathrm{MHz}, \mathrm{CDCl} 3): \delta=7.5,-22.2$. HRMS (ESI+) $\mathrm{m} / \mathrm{z}:[\mathrm{M}+\mathrm{Na}]^{+}$Calcd for $\mathrm{C}_{12} \mathrm{H}_{30} \mathrm{Si}_{3} \mathrm{O}_{4} \mathrm{Na}$ 345.1344, Found 345.1336.

Synthesis of Ethyl 5-(1,1,1,3,5,5,5-heptamethyltrisiloxan-3$y l$ )pentanoate $(\mathbf{3 i})$. The title compound $\mathbf{3 i}$ was obtained as a colorless liquid $(152 \mathrm{mg})$ in $93 \%$ isolated yield. ${ }^{1} \mathrm{H}$ NMR (300 $\left.\mathrm{MHz}_{\mathrm{CDCl}}\right): \delta=4.11(\mathrm{q}, J 7.1 \mathrm{~Hz}, 2 \mathrm{H}), 2.28(\mathrm{t}, J=7.0 \mathrm{~Hz}$, $2 \mathrm{H}), 1.63(\mathrm{p}, J=7.0 \mathrm{~Hz}, 2 \mathrm{H}), 1.34(\mathrm{~m}, 2 \mathrm{H}), 1.24(\mathrm{t}, J=7.0$ $\mathrm{Hz}, 3 \mathrm{H}$ ), 0.46 (nfom, 2H), 0.07 (s, 18H), -0.01 (s, 3H). ${ }^{13} \mathrm{C}\left\{{ }^{1} \mathrm{H}\right\}$ NMR $\left(75 \mathrm{MHz}, \mathrm{CDCl}_{3}\right): \delta=174.0,60.3,34.3,28.5$, 22.9, 17.4, 14.4, 2.0, -0.2. ${ }^{29} \mathrm{Si}\left\{{ }^{1} \mathrm{H}\right\} \mathrm{NMR}(60 \mathrm{MHz}, \mathrm{CDCl} 3): \delta$ $=7.1,-24.8$. HRMS $(\mathrm{ESI}+) \mathrm{m} / \mathrm{z}:[\mathrm{M}+\mathrm{Na}]^{+}$Calcd for $\mathrm{C}_{14} \mathrm{H}_{34} \mathrm{Si}_{3} \mathrm{O}_{4} \mathrm{Na}$ 373.1657, Found 373.1653.

Synthesis of 1,1,1,3,5,5,5-heptamethyl-3-(3-(oxiran-2ylmethoxy)propyl)trisiloxane (3j). The title compound $\mathbf{3 j}$ was obtained as a colorless liquid $(151 \mathrm{mg})$ in $95 \%$ isolated yield. ${ }^{1} \mathrm{H}$ NMR $\left(300 \mathrm{MHz}, \mathrm{CDCl}_{3}\right): \delta=3.70(\mathrm{dd}, \mathrm{J}=11.4,3.2 \mathrm{~Hz}$, $1 \mathrm{H}), 3.43(\mathrm{~m}, 2 \mathrm{H}), 3.39$ (dd, J = 11.7, $5.8 \mathrm{~Hz}, 1 \mathrm{H}), 3.16$ (dddd, 
$\mathrm{J}=5.8,4.1,3.0,2.8 \mathrm{~Hz}, 1 \mathrm{H}), 2.80(\mathrm{dd}, \mathrm{J}=4.9,4.2 \mathrm{H}), 2.62$ (dd, J =5.0, $2.6 \mathrm{~Hz}, 1 \mathrm{H}$ ), 1.61 (nfom, 2H), 0.45 (nfom, 2H), $0.08(\mathrm{~s}, 18 \mathrm{H}), 0.01(\mathrm{~s}, 3 \mathrm{H})$. The spectroscopic data correspond to the reported data. ${ }^{51}$

Synthesis of 1,1,1,3,5,5,5-heptamethyl-3(cyclohexylmethyl)trisiloxane $(\mathbf{3 k})$. The title compound $\mathbf{3 k}$ was obtained as a colorless liquid $(34 \mathrm{mg})$ in $22 \%$ isolated yield. ${ }^{1} \mathrm{H}$ NMR $\left(300 \mathrm{MHz}, \mathrm{CDCl}_{3}\right): \delta=1.74-1.56(\mathrm{~m}, 5 \mathrm{H})$, 1.46-1.34 (m, 1H), 1.28-1.10 (m, 3H), 0.97-0.85 (m, 2H), 0.43 $(\mathrm{d}, J 6.9 \mathrm{~Hz}, 2 \mathrm{H}), 0.09(\mathrm{~s}, 18 \mathrm{H}), 0.01(\mathrm{~s}, 3 \mathrm{H}) .{ }^{13} \mathrm{C}\left\{{ }^{1} \mathrm{H}\right\} \mathrm{NMR}$ $\left(75 \mathrm{MHz}, \mathrm{CDCl}_{3}\right): \delta=36.8,33.6,26.8(2 \mathrm{xC}$ according to HSQC), 26.5, 2.0, 1.1. ${ }^{29} \mathrm{Si}\left\{{ }^{1} \mathrm{H}\right\} \mathrm{NMR}\left(60 \mathrm{MHz}, \mathrm{CDCl}_{3}\right): \delta=$ 6.6, -21.9. HRMS (ESI+) $\mathrm{m} / \mathrm{z}:[\mathrm{M}+\mathrm{Na}]+$ Calcd for $\mathrm{C}_{14} \mathrm{H}_{34} \mathrm{Si}_{3} \mathrm{O}_{2} \mathrm{Na} 341.1759$, Found 341.1754.

Synthesis of methyl 18-(1,1,1,3,5,5,5-heptamethyltrisiloxan-3$y l)$ octadecanoate $(3 \mathrm{l})$. After general purification procedure the remaining liquid contained methyl oleate isomer(s) and $3 \mathbf{3}$. Using Ag-salt procedure ${ }^{52}$ to bind unreacted unsaturated fatty acid esters allows obtaining $\mathbf{3 1}$ in higher purity than with just normal silica column chromatography. The title compound $\mathbf{3 l}$ was obtained as a slightly yellow dense liquid $(111 \mathrm{mg})$ in $45 \%$ isolated yield. ${ }^{1} \mathrm{H}$ NMR $\left(300 \mathrm{MHz}, \mathrm{CDCl}_{3}\right): \delta=3.66(\mathrm{~s}$, $3 \mathrm{H}), 2.30(\mathrm{t}, J 7.5 \mathrm{~Hz}, 2 \mathrm{H}), 1.60(\mathrm{p}, J 7.2 \mathrm{~Hz}, 2 \mathrm{H}), 1.29-1.22$ (br. s, 28H), 0.44 (nfom, 2H), 0.08 (s, 18H), 0.01 (s, 3H). ${ }^{13} \mathrm{C}\left\{{ }^{1} \mathrm{H}\right\}$ NMR $\left(75 \mathrm{MHz}, \mathrm{CDCl}_{3}\right): \delta=174.5,51.6,34.3,33.4$, 29.9, 29.87-29.85 (3xC), 29.84, 29.81, 29.76, 29.75, 29.6, 29.5, 29.4, 29.3, 25.1, 23.2, 17.8, 2.0, -0.1. ${ }^{29} \mathrm{Si}\left\{{ }^{1} \mathrm{H}\right\}$ NMR $(60$ $\mathrm{MHz}, \mathrm{CDCl} 3): \delta=6.8,-21.2$. HRMS (ESI+) m/z: $[\mathrm{M}+\mathrm{Na}]^{+}$ Calcd for $\mathrm{C}_{26} \mathrm{H}_{58} \mathrm{Si}_{3} \mathrm{O}_{4} \mathrm{Na}$ 541.3535, Found 541.3531. Partial peaks belonging to unknown $\mathrm{C} 18: 1$ monosaturated fatty acid isomer(s). ${ }^{1} \mathrm{H}$ NMR (300 MHz, $\left.\mathrm{CDCl}_{3}\right): \delta=5.37,3.66,1.98$, 1.29-1.22 (br. s), 0.87 (t, J 6.3 Hz). ${ }^{13} \mathrm{C}$ NMR $(75 \mathrm{MHz}$, $\left.\mathrm{CDCl}_{3}\right): \delta=32.1,29.5,22.9,14.3$.

\section{ASSOCIATED CONTENT}

Supporting Information. The supporting information is available free of charge on the Internet at http://pubs.acs.org at DOI: XXX Copies of STEM, UV-vis, and DRIFT images, and liquid state ${ }^{1} \mathrm{H}$, ${ }^{13} \mathrm{C}$ and ${ }^{29} \mathrm{Si}$ NMR spectra (PDF).

\section{AUTHOR INFORMATION}

\section{Corresponding Author}

*E-mail: chloe.thieuleux@univ-lyon1.fr

\section{Present Address}

IV.M. now works at IRCELYON - UMR 5256 CNRS-UCBL, Villeurbanne

\section{Author Contributions}

The manuscript was written through contributions of M. J, C. C, V. M. and C. T. All authors have given approval to the final version of the manuscript.

\section{Notes}

The authors declare no conflict of interest.

\section{ACKNOWLEDGMENT}

This work was performed in the frame of an ANR project (ANR13-CDII0007 program - project acronym: HYSINANO) and the CNRS-MOMENTUM 2017 program. One patent has been filed based on the work described in this article.

\section{REFERENCES}

(1) Marciniec, B.; Maciejewski, H.; Pietraszuk, C.; Pawluc, P. Hydrosilylation A Comprehensive Review on Recent Advances; 2009.

2) During January 2019-January 2020 platinum price has varied 780-1020 USD per troy ounce https://www.nasdaq.com/marketactivity/commodities/pl\%3Anmx.

(3) Du, X.; Huang, Z. Advances in Base-Metal-Catalyzed Alkene Hydrosilylation. ACS Catal. 2017, 7 (2), 1227-1243.

(4) Sun, J.; Deng, L. Cobalt Complex-Catalyzed Hydrosilylation of Alkenes and Alkynes. ACS Catal. 2016, 6 (1), 290-300.

(5) Bart, S. C.; Lobkovsky, E.; Chirik, P. J. Preparation and Molecular and Electronic Structures of Iron(0) Dinitrogen and Silane Complexes and Their Application to Catalytic Hydrogenation and Hydrosilation. J. Am. Chem. Soc. 2004, 126 (42), 13794-13807.

(6) Hojilla Atienza, C. C.; Tondreau, A. M.; Weller, K. J.; Lewis, K. M.; Cruse, R. W.; Nye, S. A.; Boyer, J. L.; Delis, J. G. P.; Chirik, P. J. High-Selectivity Bis(Imino)Pyridine Iron Catalysts for the Hydrosilylation of 1,2,4-Trivinylcyclohexane. ACS Catal. 2012, 2 (10), 2169-2172.

(7) Pappas, I.; Treacy, S.; Chirik, P. J. Alkene Hydrosilylation Using Tertiary Silanes with $\alpha$-Diimine Nickel Catalysts. RedoxActive Ligands Promote a Distinct Mechanistic Pathway from Platinum Catalysts. ACS Catal. 2016, 6 (7), 4105-4109.

(8) Schuster, C. H.; Diao, T.; Pappas, I.; Chirik, P. J. Bench-Stable, Substrate-Activated Cobalt Carboxylate Pre-Catalysts for Alkene Hydrosilylation with Tertiary Silanes. ACS Catal. 2016, 6 (4), 2632-2636.

(9) Tondreau, A. M.; Atienza, C. C. H.; Weller, K. J.; Nye, S. A.; Lewis, K. M.; Delis, J. G. P.; Chirik, P. J. Iron Catalysts for Selective Anti-Markovnikov Alkene Hydrosilylation Using Tertiary Silanes. Science (80-. ). 2012, 335 (6068), 567 LP 570 .

(10) Buslov, I.; Keller, S. C.; Hu, X. Alkoxy Hydrosilanes As Surrogates of Gaseous Silanes for Hydrosilylation of Alkenes. Org. Lett. 2016, 18 (8), 1928-1931.

(11) Basu, D.; Gilbert-Wilson, R.; Gray, D. L.; Rauchfuss, T. B.; Dash, A. K. Fe and Co Complexes of Rigidly Planar PhosphinoQuinoline-Pyridine Ligands for Catalytic Hydrosilylation and Dehydrogenative Silylation. Organometallics 2018, 37 (16), 2760-2768.

Chen, J.; Xi, T.; Lu, Z. 10 Gram-Scale Synthesis of a Chiral Oxazoline Iminopyridine Ligand and Its Applications. Org. Chem. Front. 2018, 5 (2), 247-253.

Lee, K. L. (Aminomethyl)Pyridine Complexes for the CobaltCatalyzed Anti-Markovnikov Hydrosilylation of Alkoxy- or Siloxy(Vinyl)Silanes with Alkoxy- or Siloxyhydrosilanes. Angew. Chemie Int. Ed. 2017, 56 (13), 3665-3669.

Liu, Y.; Deng, L. Mode of Activation of Cobalt(II) Amides for Catalytic Hydrosilylation of Alkenes with Tertiary Silanes. J. Am. Chem. Soc. 2017, 139 (5), 1798-1801.

(15) Noda, D.; Tahara, A.; Sunada, Y.; Nagashima, H. Non-PreciousMetal Catalytic Systems Involving Iron or Cobalt Carboxylates and Alkyl Isocyanides for Hydrosilylation of Alkenes with Hydrosiloxanes. J. Am. Chem. Soc. 2016, 138 (8), 2480-2483.

(16) Sanagawa, A.; Nagashima, H. Cobalt(0) and Iron(0) Isocyanides as Catalysts for Alkene Hydrosilylation with Hydrosiloxanes. Organometallics 2018, 37 (17), 2859-2871.

(17) Chen, J.; Guo, J.; Lu, Z. Recent Advances in Hydrometallation of Alkenes and Alkynes via the First Row Transition Metal Catalysis. Chinese J. Chem. 2018, 36 (11), 1075-1109.

(18) Mitsudome, T.; Fujita, S.; Sheng, M.; Yamasaki, J.; Kobayashi, K.; Yoshida, T.; Maeno, Z.; Mizugaki, T.; Jitsukawa, K.; Kaneda, K. Air-Stable and Reusable Cobalt Ion-Doped Titanium Oxide Catalyst for Alkene Hydrosilylation. Green Chem. 2019, 21 (16), 4566-4570.

(19) Hilal, H. S.; Suleiman, M. A.; Jondi, W. J.; Khalaf, S.; Masoud, M. M. Poly(Siloxane)-Supported Decacarbonyldimanganese(0) Catalyst for Terminal Olefin Hydrosilylation Reactions: The Effect of the Support on the Catalyst Selectivity, Activity and Stability. J. Mol. Catal. A Chem. 1999, 144 (1), 47-59.

(20) Galeandro-Diamant, T.; Suleimanov, I.; Veyre, L.; Bousquié, M.; Meille, V.; Thieuleux, C. Alkene Hydrosilylation with Supported and Unsupported Ni Nanoparticles: Strong Influence of the Ni Environment on Activity and Selectivity. Catal. Sci. 
Technol. 2019, 9 (7), 1555-1558.

(21) Zhang, Z.; Bai, L.; Hu, X. Alkene Hydrosilylation Catalyzed by Easily Assembled Ni(Ii)-Carboxylate MOFs. Chem. Sci. 2019, 10 (13), 3791-3795.

(22) Cao, L.; Lin, Z.; Peng, F.; Wang, W.; Huang, R.; Wang, C.; Yan, J.; Liang, J.; Zhang, Z.; Zhang, T.; et al. Self-Supporting Metal-Organic Layers as Single-Site Solid Catalysts. Angew. Chemie Int. Ed. 2016, 55 (16), 4962-4966.

(23) Galeandro-Diamant, T.; Zanota, M.-L.; Sayah, R.; Veyre, L.; Nikitine, C.; de Bellefon, C.; Marrot, S.; Meille, V.; Thieuleux, C. Platinum Nanoparticles in Suspension Are as Efficient as Karstedt's Complex for Alkene Hydrosilylation. Chem. Commun. 2015, 51 (90), 16194-16196.

(24) Azuma, R.; Nakamichi, S.; Kimura, J.; Yano, H.; Kawasaki, H.; Suzuki, T.; Kondo, R.; Kanda, Y.; Shimizu, K.; Kato, K.; et al. Solution Synthesis of N,N-Dimethylformamide-Stabilized IronOxide Nanoparticles as an Efficient and Recyclable Catalyst for Alkene Hydrosilylation. ChemCatChem 2018, 10 (11), 23782382.

(25) Buslov, I.; Song, F.; Hu, X. An Easily Accessed Nickel Nanoparticle Catalyst for Alkene Hydrosilylation with Tertiary Silanes. Angew. Chemie Int. Ed. 2016, 55 (40), 12295-12299.

(26) Bao, Y.; An, W.; Turner, C. H.; Krishnan, K. M. The Critical Role of Surfactants in the Growth of Cobalt Nanoparticles. Langmuir 2010, 26 (1), 478-483.

(27) Liakakos, N.; Cormary, B.; Li, X.; Lecante, P.; Respaud, M.; Maron, L.; Falqui, A.; Genovese, A.; Vendier, L.; Koïnis, S.; et al. The Big Impact of a Small Detail: Cobalt Nanocrystal Polymorphism as a Result of Precursor Addition Rate during Stock Solution Preparation. J. Am. Chem. Soc. 2012, 134 (43), 17922-17931.

(28) Zacharaki, E.; Kalyva, M.; Fjellvåg, H.; Sjåstad, A. O. Burst Nucleation by Hot Injection for Size Controlled Synthesis of $\varepsilon$ Cobalt Nanoparticles. Chem. Cent. J. 2016, 10 (1), 10.

(29) Osuna, J.; de Caro, D.; Amiens, C.; Chaudret, B.; Snoeck, E.; Respaud, M.; Broto, J.-M.; Fert, A. Synthesis, Characterization, and Magnetic Properties of Cobalt Nanoparticles from an Organometallic Precursor. J. Phys. Chem. 1996, 100 (35), 14571-14574.

(30) Respaud, M.; Broto, J. M.; Rakoto, H.; Fert, A. R.; Thomas, L.; Barbara, B.; Verelst, M.; Snoeck, E.; Lecante, P.; Mosset, A.; et al. Surface Effects on the Magnetic Properties of Ultrafine Cobalt Particles. Phys. Rev. B 1998, 57 (5), 2925-2935.

(31) Yang, H. T.; Shen, C. M.; Wang, Y. G.; Su, Y. K.; Yang, T. Z.; Gao, H. J. Stable Cobalt Nanoparticles Passivated with Oleic Acid and Triphenylphosphine. Nanotechnology 2003, 15 (1), 70-74.

(32) Sandl, S.; Schwarzhuber, F.; Pöllath, S.; Zweck, J.; Wangelin, A. J. von. Olefin- Stabilized Cobalt Nanoparticles for $\mathrm{C}=\mathrm{C}$, $\mathrm{C}=\mathrm{O}$, and $\mathrm{C}=\mathrm{N}$ Hydrogenations. Chem. - A Eur. J. 2018, 24 (14), 3403-3407.

(33) Zola, A. S.; Ribeiro, R. U.; Bueno, J. M. C.; Zanchet, D.; Arroyo, P. A. Cobalt Nanoparticles Prepared by Three Different Methods. J. Exp. Nanosci. 2014, 9 (4), 398-405.

(34) Baudouin, D.; Szeto, K. C.; Laurent, P.; De Mallmann, A.; Fenet, B.; Veyre, L.; Rodemerck, U.; Copéret, C.; Thieuleux, C. Nickel-Silicide Colloid Prepared under Mild Conditions as a Versatile Ni Precursor for More Efficient CO2 Reforming of CH4 Catalysts. J. Am. Chem. Soc. 2012, 134 (51), 2062420627.

(35) Tondreau, A. M.; Atienza, C. C. H.; Darmon, J. M.; Milsmann, C.; Hoyt, H. M.; Weller, K. J.; Nye, S. A.; Lewis, K. M.; Boyer, J.; Delis, J. G. P.; et al. Synthesis, Electronic Structure, and Alkene Hydrosilylation Activity of Terpyridine and Bis(Imino)Pyridine Iron Dialkyl Complexes. Organometallics 2012, 31 (13), 4886-4893.

(36) Belyakova, Z. V; Pomerantseva, M. G.; Efimova, L. A.; Chernyshev, E. A.; Storozhenko, P. A. Effect of Catalysts on the
Reaction of Allyl Esters with Hydrosilanes. Russ. J. Gen. Chem. 2010, 80 (4), 728-733.

(37) Igarashi, M.; Kobayashi, T.; Sato, K.; Ando, W.; Matsumoto, T.; Shimada, S.; Hara, M.; Uchida, H. Selective Hydrosilylation of Allyl Esters with Octahydridosilsesquioxane. J. Organomet. Chem. 2013, 725, 54-59.

(38) Igarashi, M.; Matsumoto, T.; Kobayashi, T.; Sato, K.; Ando, W.; Shimada, S.; Hara, M.; Uchida, H. Hydrosilylation of Allyl Derivatives with T, D and M Type Hydrosilanes. J. Organomet. Chem. 2014, 749, 421-427.

(39) Rock, C. L.; Trovitch, R. J. Anti-Markovnikov Terminal and Gem-Olefin Hydrosilylation Using a K4-Diimine Nickel Catalyst: Selectivity for Alkene Hydrosilylation over Ether C-O Bond Cleavage. Dalt. Trans. 2019, 48 (2), 461-467.

(40) Reichel, C. L.; Wrighton, M. S. Photochemistry of Cobalt Carbonyl Complexes Having a Cobalt-Silicon Bond and Its Importance in Activation of Catalysis. Inorg. Chem. 1980, 19 (12), 3858-3860.

(41) Misal Castro, L. C.; Li, H.; Sortais, J.-B.; Darcel, C. Selective Switchable Iron-Catalyzed Hydrosilylation of Carboxylic Acids. Chem. Commun. 2012, 48 (85), 10514-10516.

(42) Zheng, J.; Elangovan, S.; Valyaev, D. A.; Brousses, R.; César, V.; Sortais, J.-B.; Darcel, C.; Lugan, N.; Lavigne, G. Hydrosilylation of Aldehydes and Ketones Catalyzed by HalfSandwich Manganese(I) N-Heterocyclic Carbene Complexes. Adv. Synth. Catal. 2014, 356 (5), 1093-1097.

(43) Dombra, J; Helleu, C; Darcel, C.; Sortais, J.-B. Cobalt Carbonyl-Based Catalyst for Hydrosilylation of carboxamides, Adv. Synth. Catal. 2013, 355 (17), 3358-3362

(44) Srinivas, V.; Nakajima, Y.; Ando, W.; Sato, K.; Shimada, S. (Salicylaldiminato)Ni(Ii)-Catalysts for Hydrosilylation of Olefins. Catal. Sci. Technol. 2015, 5 (4), 2081-2084.

(45) Chen, C.; Hecht, M. B.; Kavara, A.; Brennessel, W. W.; Mercado, B. Q.; Weix, D. J.; Holland, P. L. Rapid, Regioconvergent, Solvent-Free Alkene Hydrosilylation with a Cobalt Catalyst. J. Am. Chem. Soc. 2015, 137 (41), 1324413247.

(46) Buslov, I.; Becouse, J.; Mazza, S.; Montandon-Clerc, M.; Hu, X. Chemoselective Alkene Hydrosilylation Catalyzed by Nickel Pincer Complexes. Angew. Chemie Int. Ed. 2015, 54 (48), 14523-14526.

(47) Sunada, Y.; Tsutsumi, H.; Shigeta, K.; Yoshida, R.; Hashimoto, T.; Nagashima, H. Catalyst Design for Iron-Promoted Reductions: An Iron Disilyl-Dicarbonyl Complex Bearing Weakly Coordinating H2-(H-Si) Moieties. Dalt. Trans. 2013, 42 (48), 16687-16692.

(48) Jia, X.; Huang, Z. Conversion of Alkanes to Linear Alkylsilanes Using an Iridium-Iron-Catalysed Tandem DehydrogenationIsomerization-Hydrosilylation. Nat. Chem. 2015, 8, 157.

(49) Bokka, A.; Jeon, J. Regio- and Stereoselective Dehydrogenative Silylation and Hydrosilylation of Vinylarenes Catalyzed by Ruthenium Alkylidenes. Org. Lett. 2016, 18 (20), 5324-5327.

(50) Iimura, T.; Akasaka, N.; Kosai, T.; Iwamoto, T. A Pt(0) Complex with Cyclic (Alkyl)(Amino)Silylene and 1,3-Divinyl1,1,3,3-Tetramethyldisiloxane Ligands: Synthesis, Molecular Structure, and Catalytic Hydrosilylation Activity. Dalt. Trans. 2017, 46 (27), 8868-8874.

(51) Kong, C. J.; Gilliland, S. E.; Clark, B. R.; Gupton, B. F. HighlyActive, Graphene-Supported Platinum Catalyst for the Solventless Hydrosilylation of Olefins. Chem. Commun. 2018, 54 (95), 13343-13346.

(52) Peers, K. E.; Coxon, D. T. Simple Enrichment Procedure for the Estimation of Minor Polyunsaturated Fatty Acids in Food Fats. Int. J. Food Sci. Technol. 1986, 21 (4), 463-469. 